\title{
IL6R Gene Product
}

National Cancer Institute

\section{Source}

National Cancer Institute. IL6R Gene Product. NCI Thesaurus. Code C156001.

A protein encoded by the IL6R gene. 